\title{
National parks and social tensions - Case study Ugandan Rwenzori National Park
}

\author{
Ernst Steinicke \& Kabann I.B. Kabananukye
}

Keywords: Uganda, Rwenzori National Park, kingdoms, ethnic tension, population pressure

\section{Abstract}

The current study focuses on conflicts about land resources. As a case in point, it discusses the ethno-demographic consequences of establishing the Rwenzori Mountains National Park (RMNP) in 1992 against the express wishes of the autochthonous population. Forced out of the mountain forests into the eastern Rwenzori foothills, the Konzo, Amba and Toro peoples have faced a strict ban on expanding settlements uphill or on using land above $2200 \mathrm{~m}$ without permission. The resulting population pressure in the foothills has quickly led to tensions between the three autochthonous peoples and dozens of other ethnic groups who have joined them in recent decades. In contrast to life in the mountains, the foothills are characterized by fairly vigorous economic activity, including cement, cobalt, tea and cotton production, the main sources of employment. Ethno-social problems in western Uganda are compounded by a strengthening of the traditional kingdoms and notably by the establishment of a new Rwenzori Kingdom for the Bakonzo', a sectioned-off enclave of the Toro Kingdom. The plethora of new kingdoms since 2009 has triggered widespread social unrest, and Bakonzo expectations of privileged access to the labour market in their newly-created kingdom are especially troubling.
Profile

Protected area

Rwenzori Mountains National Park

Mountain Range

Rwenzori Mountains

Country

Uganda

\section{Problem statement, status of research and study concept}

In Uganda land-resource-based conflicts are on the increase, often degenerating into violence, loss of lives and destruction of property, including destruction of the environment. Overall, this study seeks to analyse the ethno-demographic consequences of the establishment of Rwenzori Mountains National Park (RMNP), which spawned or aggravated such conflicts.

The events around the Arab Spring have sidelined the Egyptian resistance to the new draft Nile treaty (see, for instance, The Economist, 10 May 2010), which emphasizes the enormous importance of the Nile headwaters, from international media. The rain forest ecosystem of the Rwenzori Mountains, where the highest sources of the Nile - in part fed by glaciers are situated, regulate the regional water supply and, as it passes through the George, Edward, and Albert lakes, ensure a regular inflow into the Albert Nile and the White Nile. It is therefore not surprising that this mountain range, which forms the eastern shoulder of the Central African Rift Valley is under protection.

While on the Democratic Republic of Congo (Congolese) side the Virunga National Park has extended into Rwenzori territory since 1925, in Uganda the entire mountain range above an elevation of $2200 \mathrm{~m}$ was not placed under protection until 1941 and then as a Forest Reserve (Osmaston et al. 1998). Fifty years later, approximately the same altitudinal zone, albeit not always clearly demarcated, was finally recognized as a national park and in 1994 declared a World Natural Heritage site.

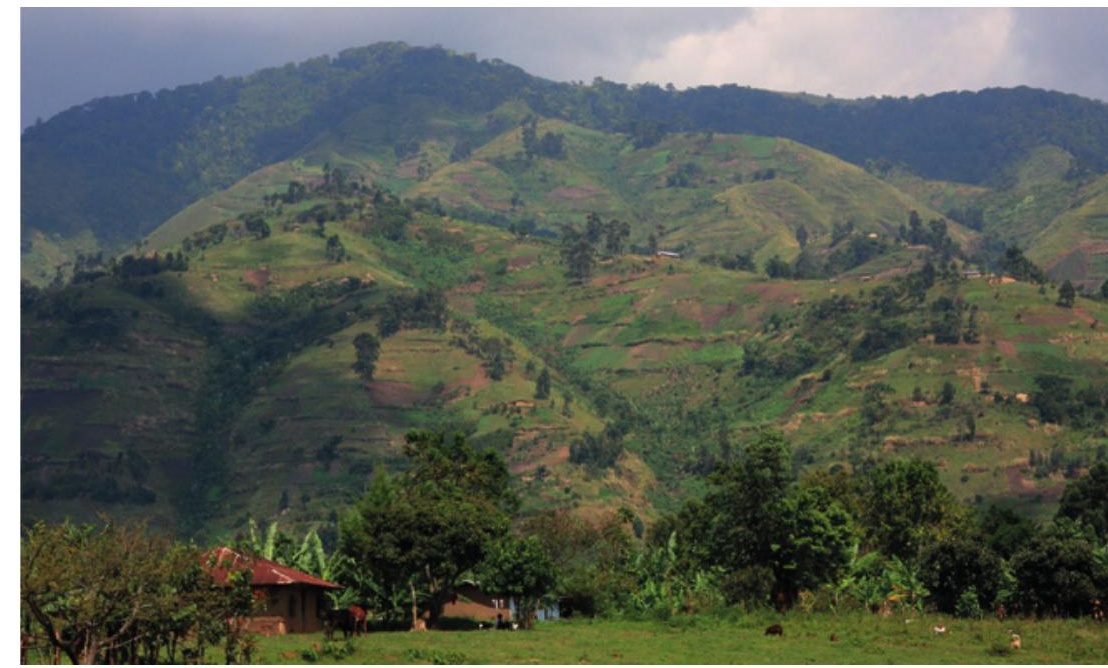

Figure 1 - Consequence of population pressure on the eastern slopes of the Rwenzori Mountains: expanding cultivation into steep areas particularly vulnerable to erosion. The timber line shown in the upper part of the photograph represents the $2200 \mathrm{~m}$ contour that defines the current boundary of the RMNP. (C) T. Zierler

The RMNP, which includes the third highest mountain in Africa, the glaciated Mt Margherita (5110 m), repeatedly served as a retreat for Congolese rebels. Its total land area of $996 \mathrm{~km}^{2}$ is state-owned and managed by the Uganda Wildlife Authority (UWA) and is therefore beyond the control of local authorities. Previously the mountain residents in the Forest Reserve were allowed to make economic use of the terrain above

\footnotetext{
1 Here, the prefixes typical for all Bantu languages are stressed, e.g., "Ba-" (= people of ...) or "Bu-" (= kingdom of ...). It should be noted in particular that the spelling of tribal names is not always consistent (example: Konzo - Khonzo - Konjo).
} 


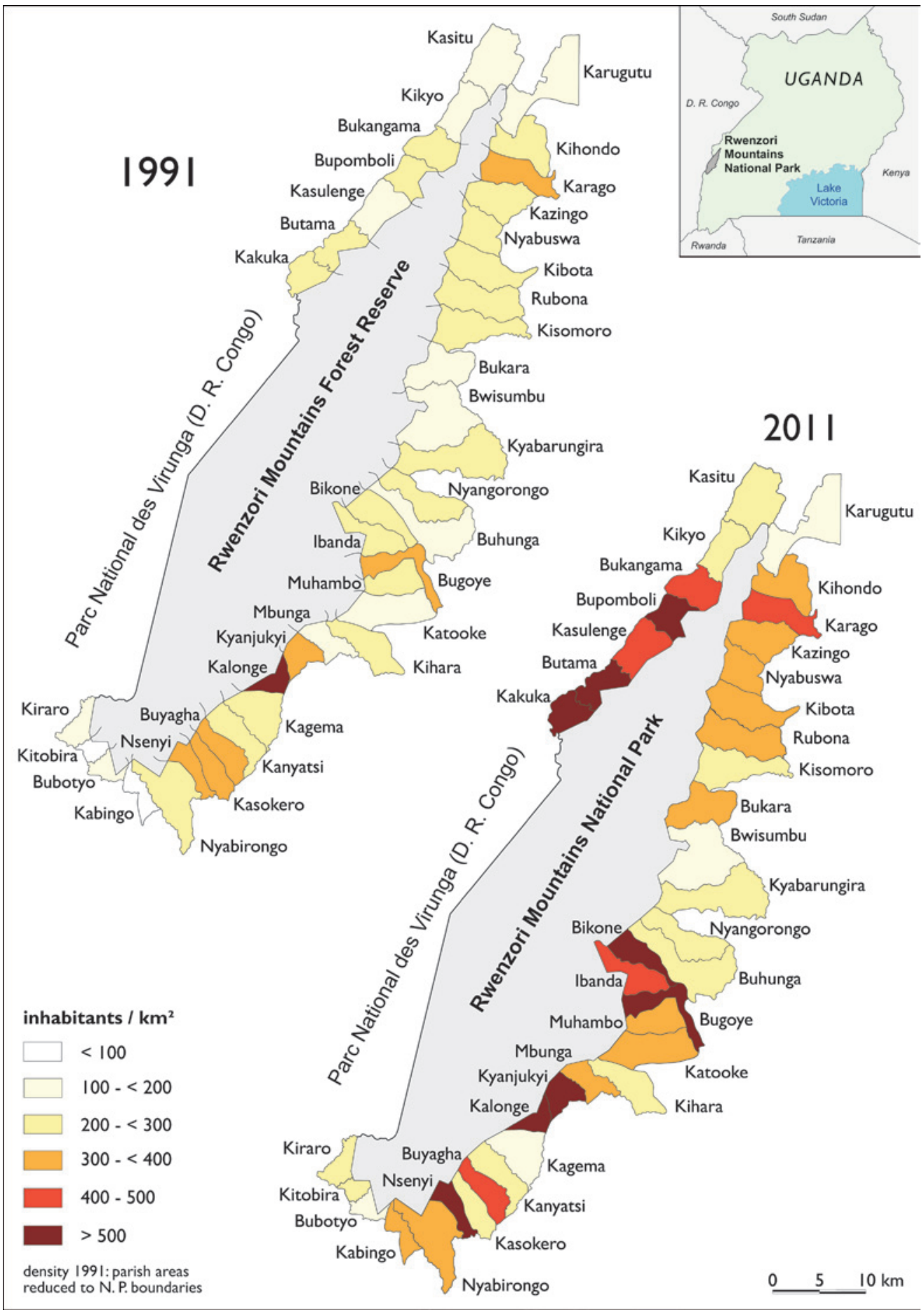

Figure 2 - Population densities in the mountain parishes immediately around the RMNP 1991 and 2011. Source: Craddock Williams (1998: 219, modified) and Steinicke (2011, modified); data acquisition by the authors and calculation in the UBOS (Kampala) 2013; designed by the authors.

$2200 \mathrm{~m}$, sometimes to develop land for settlement at high altitudes and there also to pursue their traditional religious rituals and medicine therapies. Beyond that the forested areas were inhabited by some Sua pygmies. ${ }^{2}$ In 1992 this was prohibited, as was any nonpermitted entry into the park. These access restrictions triggered a series of social tensions that form the

2 The Sua people have traditionally lived in woodlands, most of them in the lowlands of the neighbouring Semliki forests, but according to Kabananukye (2006) some of them migrated into the Rwenzori mountains. linchpin of the following discussion. Areas that have been placed under protection solely because of their ecological significance, without participation of the local population, do not conform to a modern interpretation of sustainability. This phenomenon is familiar from the national parks of Nepal (Müller-Böker 2000, 2002) and Malaysia (Backhaus 2004, 2005), and occurs also in the RMNP, where large acceptance problems exist (Kabananukye 2000: 8; Kabananukye \& Robertson 2007). 
The publications on the Rwenzori region, which appeared in rather small numbers since the end of the Ugandan civil war in the mid-1980s, were initially limited to natural-scientific investigations and issues related to the creation of the national park (e.g. Tukahirwa 1988; Yeoman 1989; 1992 or Howard, Davenport \& Baltzer 1992). In relation to the RMNP, Osmaston et al. (1998) raised economic as well as environmental questions in the late 1990s. Since the mid-1990s studies on population problems in the Rwenzori region have multiplied (e.g. Syahuka-Muhindo 1994; Balyage 2005; Kabananukye 2000, 2006; Pennacini 2006; Pennacini \& Wittenberg 2008). Lately tourism-related publications and studies on poverty reduction in the Rwenzori area have also emerged (Erhard \& Steinicke 2006; Steinicke 2011). Closely linked to them is a new article comparing sustainable regional development of the Ugandan Rwenzori with the Mt Kenya area (Neuburger \& Steinicke 2012).

Previous publications on conflicts of spatial relevance around the RMNP are summarized in Osmaston et al. (1998), Erhard \& Steinicke (2006), and Steinicke (2011). The dramatic population growth in the mountains, however, lends a particular ethno-social and political-territorial explosiveness to the issues currently discussed in research.

From the analysis of current research as well as our own new observations, the present study builds on the following two main theses:

Thesis 1: Comparable to the national parks on $\mathrm{Mt}$ Kenya and Kilimanjaro (Steinicke \& Neuburger 2012; Bart et al. 2006; Wangui et al. 2012), the RMNP also restricts the traditional use of the mountain in an uphill direction. Given the high population growth, the mountain area outside the national park is subject to a considerable increase in population pressure, as well as to an ecologically unsound expansion of agricultural land that even extends (illegally) into the national park buffer zone.

Thesis 2: Associated with the unfavourable demographic and economic situation in the Rwenzori is out-migration from the mountains into the foreland. This opens up another potential for conflict with centuries-old ethnic problems between neighbouring peoples being revived.

This study will therefore address the following research questions: What is the significance of the overall migration trends in the study areas in recent decades and what essential changes could be perceived during that time? In what way (language, lifestyle, social status or discourse) does ethnicity represent a constitutive element in the socio-economic structure and the dynamics of tension at community and regional levels?

The study applies various quantitative and qualitative methods. In addition to the analysis and evaluation of the current state of research and latest official statistics and demographic estimates (of the UBOS Uganda Bureau of Statistics), various surveys were conducted in 2012 and 2013 in the Eastern foothills and forelands of the Rwenzori. They involved expert interviews (with government agencies, academics and researchers at Makerere University in Kampala, as well as with tourism cooperatives), semi-structured interviews, and focus group discussion with numerous residents in the study area. From previous studies in East Africa it was known that standardized questionnaires were difficult to apply and would not allow deep insights. Qualitative empirical field work was carried out to verify the results of the statistical analysis and interpretation. The local population's points of view were recorded along the Eastern Rwenzori flanks and in the Bundibugyo area. This intensive interviewing activity focused on the most densely populated parishes (Figure 2) and covered about 68 households, with residents from the ethnic groups of the Toro, Amba, Konjo, and Kiga. The circumstances did not allow really randomized sampling, but by applying the snowball technique a convenience sample could be avoided. In thirteen households in the foothills of the Ft Portal area we had the opportunity to stay with families for several days and share in their daily routines, getting to know the families' livelihoods, their family structures and ties, as well as their working and living conditions.

This contribution follows to a large extent the spatially oriented conflict-theoretical approach (see Ossenbrügge 1982; Flury 1983; Reiterer 1999; Reuber 1999): social tensions arise when certain actors or groups and their objectives are excluded from the political process of evaluation and decision making or are not adequately considered. Such tensions may intensify into conflicts. Critical for their development is the nature of political power relations (see Dahrendorf 1959). Spatially-related tensions often affect multiple levels of opposing interests, specifically ecological, demographic, socio-economic, cultural and political concerns. Below, their dimensions in the Rwenzori region will be discussed, from which initial strategies can be derived for management and mitigation of conflicts.

\section{Conservation and population pressure}

When the mountain residents had become aware that from 1992 on they would lose all their traditional forms of free access and utilization of the national park, such as timber extraction and grazing, spiritual and ritual uses, ${ }^{3}$ and forest clearing in some places, they were almost unanimously opposed against the establishment of the park.

\footnotetext{
This dimension should not be ignored. Sacred sites of the Bakonzo-Baamba are located inside the park. Buremba, for instance, serves as the place where their cultural founding father was buried. A recent geo-referencing of the sacred sites in Mt Rwenzori National Park, however, revealed that these sacred sites happen to lie almost along the $2200 \mathrm{~m}$ a.s.l. contour that defines the current boundary of the park. Although resource access would go on even beyond the $2200 \mathrm{~m}$ contour, settlements and cultivation were not taken above this sacred line (friendly information from Arthur Mugisha, PhD). According to Erhard \& Steinicke (2006: 249) this altitude corresponds to the upper thermal cultivation limit of banana growing.
} 
In response, Yeoman et al. (1990) suggested that more than half of the restricted area $\left(513 \mathrm{~km}^{2}\right)$ should continue to be kept as a forest reserve and to declare only the actual mountains over $3000 \mathrm{~m}$ as a national park. But the UWA, not least due to international pressure, rejected this fundamental modification of the existing plans. Efforts for nature conservation thus excluded public access to altitudes above $2200 \mathrm{~m}$. Although the population growth between mountains and foreland is not strikingly different - it varies from $2.7 \%$ to $3.0 \%$ per year (UBOS 2012) - it nevertheless generated a population pressure in the mountains which can only be reduced by out-migration.

Figure 2 illustrates how closely the approximately 300000 mountain inhabitants presently settle on the Ugandan side of the Rwenzori. In different mountain parishes, especially in the north-western and southeastern part, this sometimes results in densities of over 650 people per $\mathrm{km}^{2}$, which has serious ecological consequences in subsistence economies. The relatively high density, which Figure 2 shows for 1991, does not correspond to the actual conditions, as until 1992 the municipal borders stretched into the Forest Reserve to the state border on the Rwenzori Ridge. With this representation Craddock Williams (1998: 219) merely wanted to show the future population pressure resulting from the access restrictions.

Overall, the population in mountain villages has increased by more than two-thirds since 1991 and by a quarter since the last census in 2002 (cf. Table 1). In contrast to the situation in the foreland, immigration plays only a minor role. Mainly responsible for the increase are the very high fertility rates, which have remained unchanged for decades at over 6.2 (UBOS 2012: 10).

As Erhard \& Steinicke (2006) showed, the region is inhabited by a poor peasant community with limited use of modern agricultural technologies. Therefore, the immediate consequence of the increasing population pressure was the expansion of agricultural land use close to the edges of the national park, in some areas also connected with illegal forest clearing. In this case, however, the agricultural use of slopes vulnerable to erosion has risen steadily, which is associated with increased debris-flow activity and soil degradation. Similar to the circumstances on Mt Kenya and Kilimanjaro, the forest is limited to just those areas that lie within the park (Neuburger \& Steinicke 2012). As stated in thesis 2, such processes lead to out-migration from the mountain areas and, in turn, to an increase of the potential for ethnic conflict.

\section{Ethnic groups and kingdoms}

One of the major mountain ethnic groups, the Bakonzo, are small-scale farmers who grow crops primarily in the lower mountain areas. In Uganda they are traditionally referred to as mountain people, because they also utilize(d) the higher-altitude zones for hunt-
Table 1 - Population development in the Ugandan Rwenzori from 1991 onwards. Source: UBOS (2012; 2013); data acquisition by the authors and calculation in the UBOS (Kampala) 2013 (modifying data in http://countrystat.org/home. aspx?c=UGA\&ta=226SP0101\&tr=26).

\begin{tabular}{|l|r|r|r|}
\hline \multirow{2}{*}{ District / Territory } & \multicolumn{3}{|c|}{ Population in mountain communities } \\
\cline { 2 - 4 } & Census 1991 & Census 2002 & June 2011 \\
\hline Kasese & 101574 & 121781 & 138000 \\
\hline Kabarole & 46783 & 63712 & 78800 \\
\hline Bundibugyo & 29972 & 57132 & 87700 \\
\hline $\begin{array}{l}\text { Rwenzori } \\
\text { districts total }\end{array}$ & 178329 & 242625 & 304500 \\
\hline
\end{tabular}

ing, grazing, collecting firewood, etc., or in times of conflict sought refuge in the elevated mountain areas (Stacey 1998). They currently number around 760000 (2002 census: 610000$)$. In ethno-genetic and linguistic terms, they are closely related to the adjacent 1.7 million strong Nandi people in the DR Congo (Tucker \& Tucker 2002; Gordon 2005; Pennacini 2006).

In the north of the Rwenzori, including the foreland, the Uganda Population and Housing Census of 2002 reports just under 36000 Baamba and approximately 100 individuals of the indigenous, but strongly Bantu-infiltrated pygmies. Since 1992 the latter have been systematically expelled from the RMNP, which has led to a de facto dissolution of this ethnic group. Residual members of this population, which still numbered 120 in 1991 (Kabananukye \& Wily 1996), can still be found in the north of the Rwenzori (cf. Figure 3).

The Batoro number roughly the same as the $\mathrm{Ba}$ konzo; their distribution area corresponds to that of the old Toro Kingdom in the east of the Rwenzori (see Figure 4). After the arrival of the British colonialists, Bakonzo and Baamba (Ba Nya Rwenzururu the people of Rwenzururu mountains) were paying tribute to the king of the neighbouring Batoro.

Socially, as almost everywhere in East and Central Africa, farmers enjoy little recognition. The possession of cattle, however, is a wealth and status indicator, synonymous with belonging to the social elite. It has obvious socio-cultural significance: unlike in the eastern D.R. Congo, the different life forms in the Rwenzori region are not associated with an ethnic differentiation, in which the crop farmers (Iru or Hutu) are regarded as ethnically inferior to cattle farmers (Hima or Tutsi) and therefore seen as a subordinate group (see Brandstetter 2001). In the Toro Kingdom, all farmers - and thus the Rwenzori mountain peoples still represent the lower social class.

This traditional social stratification was exacerbated by the colonial administration system, when the British included the Bakonzo and Baamba in the Toro Kingdom. The resulting decades-long conflict between ethnic groups finally led to the foundation of the Rwenzururu Movement (Rwenzori Glacier Movement) in the 1960s that, by means of a rebellion, took the Bakonzo and Baamba out of their subordinate po- 

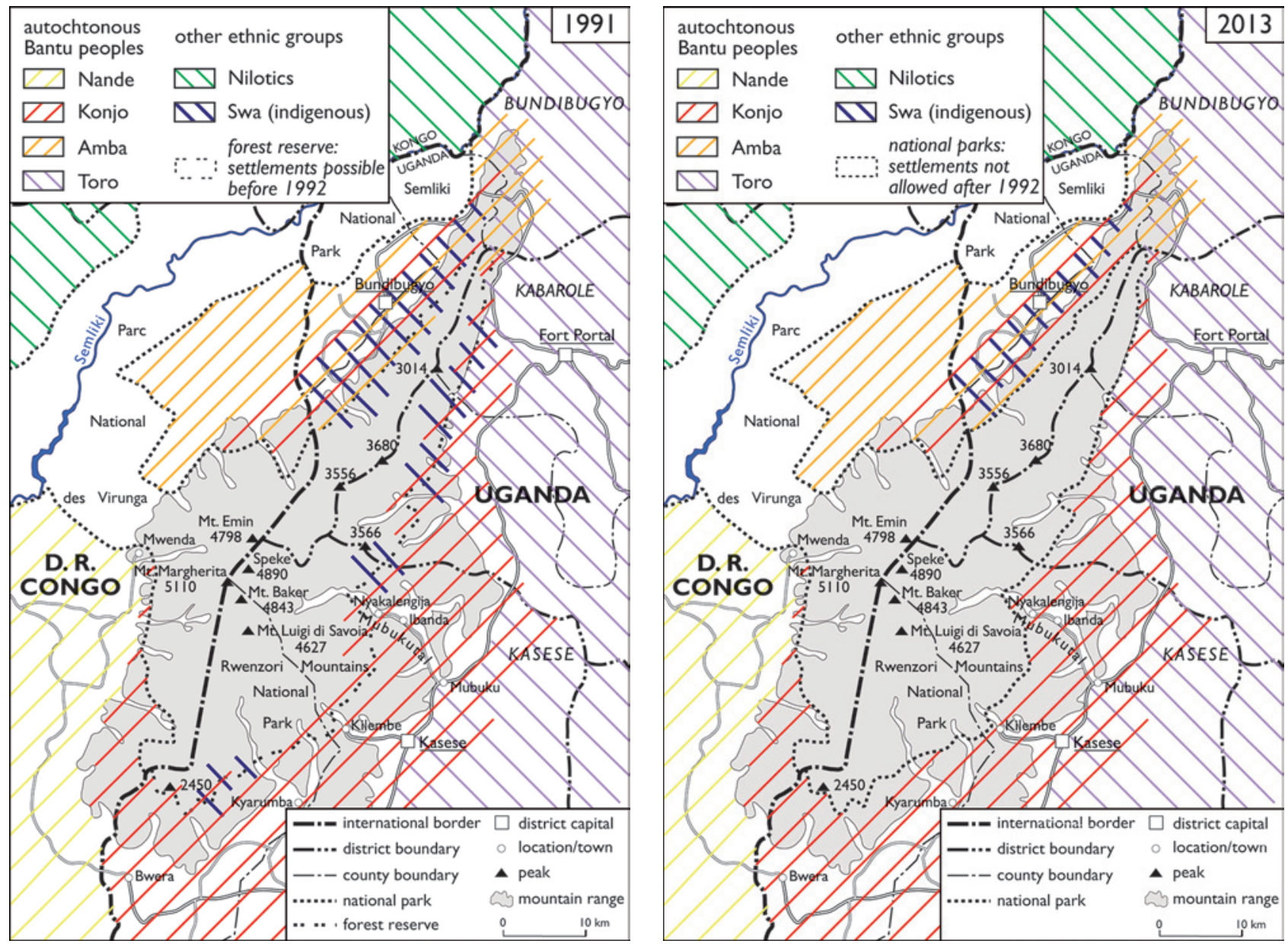

Figure 3 - Ethnic groups and administrative boundaries in the Rwenzori area 1991 and 2013. Source: Atlas Narodov Mira (Bruk \& Apenchenko 1964); Nita \& Nampa (1997); Tucker \& Tucker (2002); Gordon (2005); Kabananukye (2006); Neuburger \& Steinicke (2012); designed by the authors.

sition (Syahuka-Muhindo 1994). Even so, until 2009 the Toro Kingdom - at least officially - still extended across the entire Rwenzori region.

A major current ethno-political problem is the Rwenzururu monarchy (Obusinga bwa Rwenzururu), established (on paper) during the main phase of the rebellion of the Bakonzo and Baamba. In an official survey in $2000,85 \%$ of the Bakonzo supported the establishment of this new kingdom (Kabananukye 2000: 8; see also Balyage 2005: 517). In October 2009 the central government in Kampala finally officially agreed to the creation of the kingdom (cf. http:/ / www. rwenzururu.com; Daily Monitor January 7, 2010). The actual implementation, however, is associated with significant problems and conflicts. Apart from the vague concepts about its exact extent, the monarchy project is directed against the interests of the Batoro who are now a minority in Obusinga bwa Rwenzururu.

In contrast to the mountains, the eastern Rwenzori foreland forms a relatively dynamic economic area in which the commodity-oriented cement and cobalt production of Hima and Kasese, but also tea and cotton production stand out in the employment structure. In addition to the three autochthonous ethnic groups of the Konzo, Amba and Toro, a dozen ethnicities settled here that have immigrated in recent decades. Numerically the Bakiga from densely populated south-western Uganda play a major role. There, between 1946 and 1976, a government programme relocated some 80000 people to the northern neighbouring regions because of agricultural-social problems. Nonetheless, the influx of immigrants has continued to the present (Kichodo 2008: 116-118). Even though social problems, associated here with this mainly industrially-oriented in-migration, are less than in Bunyoro-Kitara, which was already plagued by unrest (see, for instance, Daily Monitor, 10 April 2010), they contribute generally to the increase of the ethnic conflict potential.

In addition, as pointed out before, ever more Bakonzo migrate from the mountain villages into the Rwenzori foreland. Therefore it seems to be only matter of time before existing social tensions will escalate into ethnic conflicts. The expectations of the Bakonzo to be favoured over the other ethnic groups in getting jobs in the newly created Kingdom should play an important role.

In this context, Figure 4 helps to understand an emerging and not to be underestimated conflict. The traditional monarchies - with Bunyoro-Kitara by all accounts going back to the $14^{\text {th }}$ or $15^{\text {th }}$ century - were 


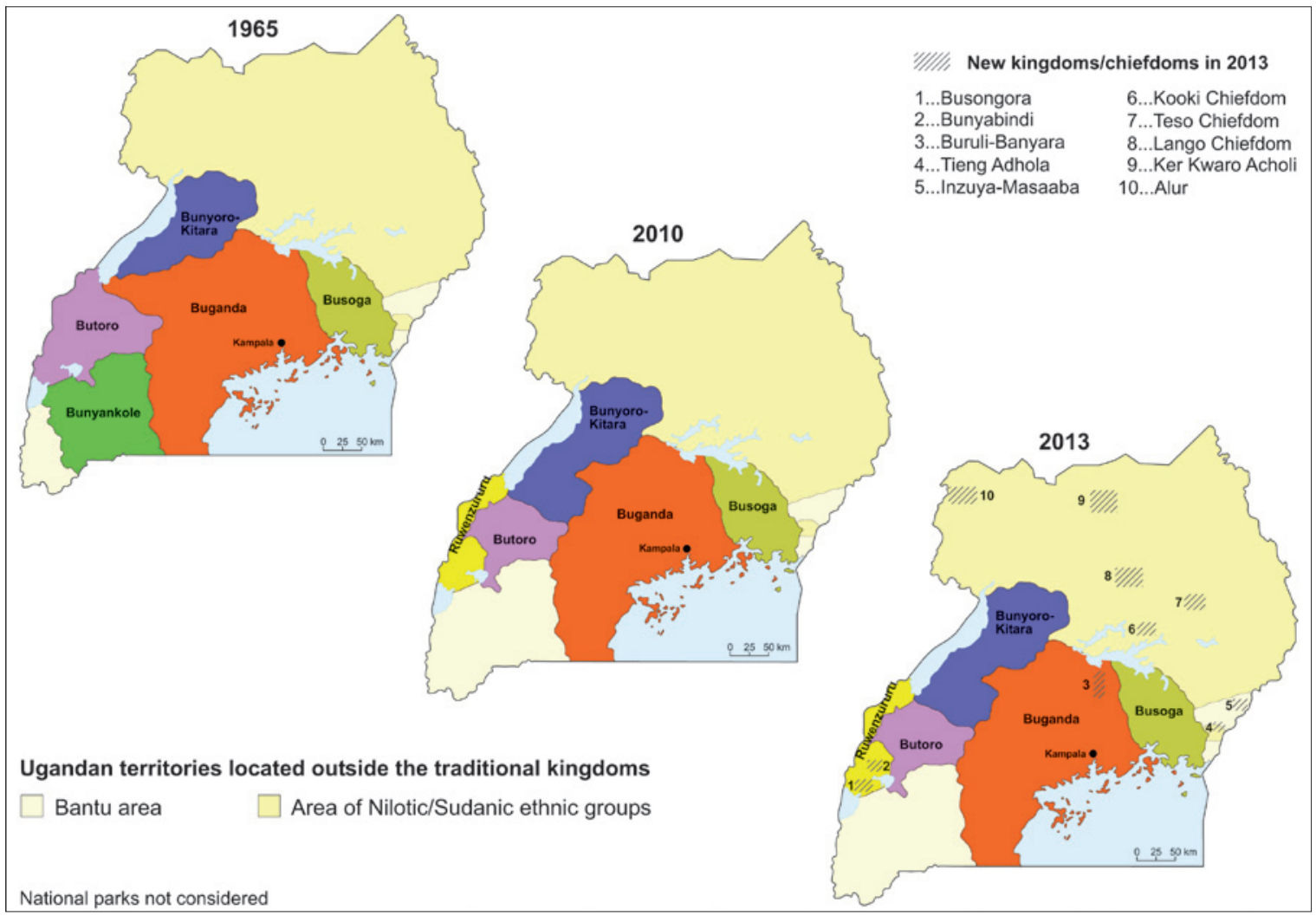

Figure 4 - Bantu kingdoms in Uganda 1965, 2010, and 2013. Source: illustration by the authors based on the Macmillan Uganda Atlas (2004: 34) and UBOS (2012), official websites of the various kingdoms (e.g. http:/ / wmw.rwenzururu.com).

banned in the 1960s and not re-established until 1993 under president Yoweri Museveni (Pakenham, 1991; Nzita \& Niwampa 1997). ${ }^{4}$ By recognizing the Rwenzururu Kingdom in 2009, however, a precedent has been set that has resulted in the proclamation of a number of other kingdoms and chiefdoms across Uganda. In the study area, this concerns the kingdoms of Busongora (founded 1 July 2012) and Bunyabindi (founded 3 August 2012). Both claim a fair part of the territory of the Rwenzururu Kingdom. Media have already reported serious ethno-political and cultural tensions (Habati 2012). Moreover, the dominance of the Bakonzo in the Obusinga bwa Rwenzururu has brewed yet another conflict: the Baamba have realized that attaining some form of kingship brings with it a basket of resources. It is therefore not surprising that they have started agitating for their own kingdom.

\section{Conclusion}

The two main theses, one building on the other, upon which the present study is based, could not be falsified. The designation of the RMNP in 1992 generated a population pressure in the mountains that forced the inhabitants to extend the agricultural land

\footnotetext{
4 It seemed reasonable to him, however, to refuse this reconstitution to his own people, the Ankole. The main reason for this is the different life forms between farmers and herders that are still interpreted ethnically among the Banyankole, which - as demonstrated in Rwanda and the Eastern Congo - is highly conflict-promoting.
}

up into the steepest terrain, which has exacerbated soil erosion and other environmentally problematic processes. Beyond that, migration out of the mountain areas has become inevitable. In the foreland, which is now part of the new Rwenzururu Kingdom, this results in ethno-political tensions with other autochthonous and in-migrated ethnic groups. Related to this, the demand for the formation of new kingdoms is a reflection of the socio-economic set of problems. Such demands are an attempt by various ethnic groups to confront contempt and cultural heteronomy. Whether this will reduce the current tensions between the ethnic groups is doubtful.

The formation of new kingdoms is a trend that is also reflected in other sub-Saharan countries; it is undoubtedly connected to the forcing-back of state authorities. Although all the recognized kingdoms in Uganda today are constitutionally merely entitled to cultural rights, their political influence is still significant. The power factor lies in their enormous land holdings.

As on Mt Kenya and on Kilimanjaro, banning traditional use of the national park areas has also brought considerable economic disadvantages for the local communities (Neuburger \& Steinicke 2012). Another study found that the income from the RMNP and alpine tourism is not sufficient to compensate for the opportunity costs (Erhard \& Steinicke 2006; Steinicke 2011). It is therefore not surprising that there is little evidence of acceptance of the RMNP among the resident population. 
As a possible, relatively short-term solution and mitigation of ethnic tensions, it would be advisable to adopt the proposal of Yeoman et al. (1990) in a modified form, i. e. to redraw the RMNP boundaries at higher altitudes. A transition zone between the park and the residential area should thus allow more leeway for the agrarian population in the mountains. Since not all tourists are actual climbers, this zone would also lend itself to community-based tourism projects without the participation of the UWA, with significant benefits for a large part of the mountain residents. It could then be expected that the population pressure in the mountains and the out-migration into the foothills and forelands would decrease.

Since the abundant oil reserves in the northern foreland of the Rwenzori should soon be extracted, basic socio-economic changes appear inevitable; longer-term considerations thus seem not very practical. The kingdoms on whose land the oil wells should operate will naturally have a say in the exploitation of resources. The demand for the creation of new kingdoms (at the expense of existing ones) may well have to be interpreted in this sense.

\section{References}

Backhaus, N. 2004. Nachhaltiger Tourismus in malaysischen Nationalparks? Koordination der Bedürfnisse von Individual- und Gruppenreisenden. Tourismus Journal 8: 87-110.

Backhaus, N. 2005. Tourism and Nature Conservation in Malaysian National Parks. Culture, Society, Environment - South Asian and South East Asian Studies 6. Münster.

Balyage, Y. 2005. Ethnic Conflict and Governmental Intolerance.The Case of Rwenzururu Kingdom in Western Uganda. In: Mukama, R. \& Murindwa-mutanga (eds.), Confronting Twenty-first Century Challenges 3: 507-522. Kampala.

Brandstetter, A.-M. 2001. Die Ethnisierung von Konflikten in Zentralafrika. In: Meyer, G. \& A. Thimm (eds.), Ethnische Konflikte in der Dritten Welt. Ursachen und Konsequenzen. Veröffentlichungen Interdisziplinärer Arbeitskereis Dritte Welt 14: 131-150. Mainz.

Bruk, S.I. \& V.S. Apenchenko 1964. Atlas Narodov Mira. Moskau.

Craddock Williams, V. 1998. The economics of conservation in the Rwenzori. In: Osmaston, H.A. J. Tukahirwa, C. Basalirwa \& J. Nyakaana (eds.), The Rwenzori Mountains National Park, Uganda: 210-220. Kampala.

Dahrendorf, R. 1959. Class and class conflict in industrial society. Stanford.

Erhard, A. \& E. Steinicke 2006. Aktuelle ethnische und sozioökonomische Entwicklungen im ugandischen Ruwenzori. Beobachtungen und Vergleiche aus dem ostafrikanischen Hochgebirge. Mitteilungen der Österreichischen Geographischen Gesellschaft 148: 241-268. Wien.
Flury, M. 1983. Krisen und Konflikte. Geographica Bernensia G20. Bern.

Habati, M.A. 2012. Tribal politics explodes. The Independent 225: 10-14. London.

Howard P., T. Davenport \& M. Baltzer 1992. Rwenzori Mountains National Park: biodiversity report. Kampala.

Kabananukye, K.I.B. 2000. Bakhonzo's Political \& Socio-Cultural Dynamics. Kampala.

Kabananukye, K.I.B. 2006. Ethnic Diversity and Cultures in the Rwenzoris. Kampala.

Kabananukye, K. \& L. Wily 1996. Report On a Study of the Abayanda Pygmies of South West Uganda For Mgahinga and Bwindi Impenetrable Forest Conservation Trust. Kampala, Mgahinga and Bwindi Impenetrable Forest Conservation Trust.

Kabananukye, K. \& A. Robertson 2007. A tourism and interpretation plan for the Batwa participation in culture based tourism around Mgabinga Gorilla National Park. Uganda Wildlife Authority Prime West - African Wildlife Foundation. Kampala.

Kichodo, H.M. 2008. Regional Geography of Uganda and Fieldwork. Paper 250/3. Kampala.

Macmillan Atlas 2004. Uganda Secondary School Atlas. Kampala.

Müller-Böker, U. 2000. Livelihood strategies and local perceptions of a new nature conservation project in Nepal - The Kanchenjunga Conservation Area Project. Mountain Research and Development 20: 324-331.

Müller-Böker, U., M. Kollmair \& R. Soliva 2002. Der Naturschutz in Nepal im gesellschaftlichen Kontext. Asiatische Studien. Zeitschrift der Schweizerischen Asiengesellschaft 2002: 725-775.

Nzita, R. \& M. Niwampa 1997. Peoples and Cultures of Uganda. $3^{\text {rd }}$ ed. Kampala.

Osmaston, H.A. et al. (eds.) 1998. The Rwenzori Mountains National Park, Uganda. Kampala.

Ossenbrügge, J. 1982. Politische Geographie als räumliche Konfliketfoschung. Konzept zur Analyse der politischen und sozialen Organisation des Raums auf der Grundlage angloamerikanischer Forschungsansätze. Hamburger Geographische Studien 40. Hamburg.

Pakenham, T. 1991. The Scramble for Africa. London.

Pennacini, C. (ed.) 2006. I popoli della luna - The People of the Moon. Ruwenzori 1906-2006. Torino.

Pennacini, C. \& H. Wittenberg (eds) 2008. Rwenzori. Histories and Cultures of an African Mountain. Kampala.

Reiterer, A. 1999. Ethnischer Konflikt. In: Reiterer, A. \& L. Flaschberger (eds.), Ethnischer Konflikt und Alltag: 9-43. Frankfurt / Main.

Reuber, P. 1999. Raumberogene politische Konflikte. Erdkundliches Wissen 131. Stuttgart.

Stacey, T. 1998. BaKonjo Identity and the Protection of Rwenzori: The Spiritual Factor. In: Osmaston, H.A., J. Tukahirwa, C. Basalirwa \& J. Nyakaana (eds.), The Rwenzori Mountains National Park, Uganda: 300-305. Kampala.

Steinicke, E. 2011. Konsequenzen der Nationalparkgründung im Ruwenzori (Uganda). Geographische Rundschau 63 (2): 57-63. Braunschweig. 
Syahuka-Muhindo, A. 1994. The Rwenzururu Movement and the Democratic Struggle. In: Mandani, M. \& J. Oloka-Onyango (eds.), Uganda: Studies in Living Conditions, Popular Movements and Constitutionalism: 273-317. Kampala.

Tukahirwa, J.M.B. 1988. Soil Ressources in the Highlands of Uganda: Prospects and Sensitivies. In: Messerli, B. \& H. Hurni (eds.), African Mountains and Highlands 8: 121-134. Bern.

Yeoman, G. 1989. Africa's Mountains of the Moon: Journeys to the Snowy Sources of the Nile. London.

Yeoman, G. 1992. Uganda's new Rwenzori National Park. In: Swara 15 (2): 16-22. Nairobi.

Yeoman, G., J. Tindigarukayo \& H. AryamanyaMugisha 1990. Rwenzori Mountains National Park: Results of public inquiry and recommendations for establishment. Kampala.

Web references (accessed all in May/June 2013):

Obusinga bwa Rwenzururu. Available at: http:// www.rwenzururu.com

Gordon, R.G. (ed.) 2005. Ethnologue: Languages of the World, $15^{\text {th }}$ ed. Dallas. Available at: http:// www.ethnologue.com/

Tucker, N.D. \& I. Tucker 2002. A survey report for the Bantu languages. SIL Electronic Survey Reports 2002-2016. Dallas. Available at: http://www.sil.org/ silesr/2002/016/

UBOS - Uganda Bureau of Statistics. CountryStat Uganda. Available at: http://countrystat.org/home. aspx?c $=\mathrm{UGA} \& \mathrm{ta}=226 \mathrm{SPO} 101 \& \mathrm{tr}=26$
UBOS - Uganda Bureau of Statistics. Statistical Abstract 2010. Available at: http://www.ubos.org/

UBOS - Uganda Bureau of Statistics. Statistical Abstract 2012. Available at: http://www.ubos.org/ onlinefiles/uploads/ubos/pdf\%20documents/2012S tatisticalAbstract.pdf

Newspaper articles:

Daily Monitor (Kampala), January 7, 2010: Obusinga has affected FDC support.

Daily Monitor (Kampala), April 10, 2010: Divisions over new constituencies.

Economist, May 10, 2010: Nile River Basin Dispute.

\section{Authors}

\section{Ernst Steinicke}

(*1954). Professor at the Institute of Geography and Dean of Study at the Faculty of Geo and Atmospheric Sciences at the University of Innsbruck, Austria, specializes in social and population geography of mountain regions.

\section{Kabann I.B. Kabananukye}

(*1955). Lecturer in Social Anthropology at Makerere University, Kampala, Uganda, and Consultant of the Ugandan Government, specializes in population studies of Uganda. 